DOI: $10.15193 /$ zntj/2017/110/178

\author{
IZABELLA KWAŚNIEWSKA-KAROLAK
}

\title{
WPLYW ZAMRAŻALNICZEGO PRZECHOWYWANIA NA ZAWARTOŚĆ WITAMINY C I WYBRANE CECHY FIZYKOCHEMICZNE OWOCÓW PAPRYKI SŁODKIEJ (CAPSICUM ANNUUM L.)
}

\author{
Streszczenie
}

Celem pracy było określenie wpływu czasu (9 tygodni) i temperatury zamrażalniczego przechowywania $\left(-20^{\circ} \mathrm{C}\right.$ i $\left.-80^{\circ} \mathrm{C}\right)$ na zawartość wybranych składników (kwasu L-askorbinowego - KA, sumy kwasu L-askorbinowego i L-dehydroaskorbinowego - KDA oraz suchej masy), jak również na kwasowość ogólną i teksturę owoców słodkiej papryki (żółtej i czerwonej) odmiany 'California'.

Podczas zamrażalniczego przechowywania całych owoców papryki następował w nich stopniowy wzrost zawartości suchej masy, istotnie zróżnicowany w zależności od czasu i temperatury przechowywania. W papryce przechowywanej w temp. $-80{ }^{\circ} \mathrm{C}$ końcowa zawartość suchej masy była istotnie mniejsza niż przechowywanej $\mathrm{w}-20^{\circ} \mathrm{C}$. Wzrost zawartości suchej masy w owocach papryki czerwonej i żółtej przechowywanej w niższej temperaturze wyniósł odpowiednio: 6,8 i 9,3 \%, natomiast w wariancie wyższej temperatury były one znacznie większe i wynosiły 14,8 \% (papryka czerwona) i 17 \% (papryka żółta). Świadczy to o mniejszym ubytku wody z owoców papryki przechowywanych w niższej temperaturze. Zaobserwowano zmniejszenie zawartości KA oraz sumy KA i KDA, przy czym był on największy w początkowym okresie przechowywania. Po zakończeniu eksperymentu średnie straty kwasu L-askorbinowego w papryce czerwonej przechowywanej w temp. $-80{ }^{\circ} \mathrm{C} \mathrm{i}-20{ }^{\circ} \mathrm{C}$ wyniosły odpowiednio: 37 i $41 \%$, natomiast w papryce żółtej - 28 i $35 \%$. Zmniejszenie sumy KA i KDA w papryce czerwonej przechowywanej w temp. $-80{ }^{\circ} \mathrm{C}$ i $-20{ }^{\circ} \mathrm{C}$ wyniosło odpowiednio: 49 i $56 \%$, a w papryce żółtej -41 i $43 \%$. Końcowa zawartość całkowitego kwasu askorbinowego w papryce przechowywanej w obu temperaturach była do siebie zbliżona, natomiast istotnie większą zawartość KA stwierdzono w owocach obu rodzajów papryki przechowywanych $w-80^{\circ} \mathrm{C}$. Kwasowość ogólna papryki wzrosła ok. dwukrotnie z 0,26 do $0,49 \mathrm{mg} / 100 \mathrm{~g}$ kwasu jabłkowego w przypadku obu wariantów temperaturowych przechowywania papryki żółtej oraz z 0,25 do 0,54 i $0,52 \mathrm{mg} / 100 \mathrm{~g}$ kwasu jabłkowego w przypadku papryki czerwonej przechowywanej odpowiednio: w temp. $-20{ }^{\circ} \mathrm{C}$ i $-80^{\circ} \mathrm{C}$. Wartość kwasowości uległa zmianom niezależnie od zastosowanej temperatury zamrażalniczego przechowywania. Tekstura papryki zmieniła się szczegól-

Dr I. Kwaśniewska-Karolak, Instytut Technologii i Analizy Żywności, Wydz. Biotechnologii i Nauk o Żywności, Politechnika Łódzka, ul. Stefanowskiego 4/10, 90-924, Łódź.

Kontakt: izabella.kwasniewska-karolak@p.lodz.pl 
nie $\mathrm{w}$ pierwszym tygodniu zamrażalniczego przechowywania. Zmiany te były bardziej intensywne w owocach przechowywanych w temp. $-20^{\circ} \mathrm{C}$.

Słowa kluczowe: papryka zamrożona, witamina C, sucha masa, kwasowość, tekstura

\section{Wprowadzenie}

Warzywa i owoce są nieodłącznym elementem diety. Zaleca się ich spożywanie 5 razy dziennie. Produkty roślinne są bogatym źródłem witamin, składników mineralnych, kwasów organicznych oraz błonnika pokarmowego [8]. Owoce papryki charakteryzuje szczególny skład chemiczny. Odmiany słodkie i ostre są wykorzystywane do produkcji przypraw, mrożonek oraz marynat. Często papryka wykorzystywana jest do produkcji tzw. produktów gotowych do spożycia (ready to cook) na zimno lub na ciepło oraz żywności wygodnej [26]. W branży kulinarnej papryka nadaje się do przyrządzania potraw smażonych oraz pieczonych z mięsem, ryżem i rybami lub jako dodatek do sałatek poprawiający barwę oraz smak potraw [1].

Papryka słodka, nazywana również pieprzowcem rocznym (Capsicum annuum), należy do warzyw jednorocznych z rodziny psiankowatych. Częścią jadalną jest jagoda o twardych, soczystych ścianach, w której może znajdować się od 2 do 6 komór [25]. Poszczególne odmiany charakteryzują się różną wielkością owoców, a w zależności od kształtu wyróżnia się owoce duże, długie, cienkie, spłaszczone, owalne oraz okrągłe. Barwa papryki może być zielona, biała, żółta, pomarańczowa, czerwona oraz fioletowa. Barwa zielona może także świadczyć o niedojrzałej formie papryki czerwonej, żółtej i pomarańczowej. Jest to cecha odmianowa, stąd pozostałe odmiany nie zmieniają barwy z zielonej na właściwą. Smak papryki może być pikantny (duża zawartość kapsaicyny) lub słodki (znikoma zawartość kapsaicyny) [7, 8]. W Polsce najpopularniejszą odmianą uprawową jest papryka 'King Arthur'. Jedną z powszechnie wykorzystywanych odmian papryki, nie tylko w kuchni azjatyckiej i meksykańskiej, jest papryczka chilli, która swój charakterystyczny, ostry smak zawdzięcza obecności alkaloidu - kapsaicyny. Kapsaicyna cechuje się oddziaływaniem prozdrowotnym na organizm człowieka [1]. Stężenie kapsaicyny mierzy się w jednostkach Scoville'a. Najostrzejsze w smaku papryczki należą do gatunku Habanero (Capsicum chinense) ich ostrość wynosi od 200000 do 350000 jednostek. Papryczki o niezbyt ostrym smaku mają moc ponad 300-krotnie mniejszą, wynoszącą ok. 600 jednostek.

Papryka zaliczana jest do grupy produktów bogatych w witaminę $\mathrm{C}$, zawiera jej więcej niż owoce cytrusowe. Poza witaminą $C$ papryka jest dobrym źródłem $\beta$-karotenu oraz flawonoidów, które mogą wykazywać działanie przeciwnowotworowe [25]. Zawartość poszczególnych składników odżywczych jest zależna od stopnia dojrzałości, jak i odmiany. Owoce bardziej dojrzałe zawierają tych składników więcej niż owoce niedojrzałe lub słabo wybarwione [29]. Odmiany czerwone charakteryzują się 
ok. 16-krotnie większą zawartością prowitaminy A w porównaniu z odmianami zielonymi. Zawartość $\beta$-karotenu w 100 g papryki czerwonej wynosi $3165 \mu \mathrm{g}$, natomiast w papryce zielonej - jedynie $193 \mu \mathrm{g}$ [8].

Głównymi procesami, które zachodzą w warzywach po zbiorze są oddychanie oraz transpiracja. Są to procesy przyczyniające się do zmian jakości, utraty masy, starzenia się oraz psucia [4]. Ze względu na ograniczoną trwałość, warzywa i owoce po zbiorze powinny być w jak najkrótszym czasie spożyte bądź przetworzone. Sposobem pozwalającym zachować najwyższą jakość i wartość odżywczą jest zamrażanie i zamrażalnicze przechowywanie [13]. Całkowite utrwalenie produktów pochodzenia roślinnego uzyskuje się w temp. $-18{ }^{\circ} \mathrm{C}$ i niższej. Produkty mrożone i głęboko mrożone (temp. $-12{ }^{\circ} \mathrm{C}$ i $-18^{\circ} \mathrm{C}$ ) można przechowywać od kilku do kilkunastu miesięcy. Metoda ta pozwala zachować w stopniu jak najmniej zmienionym walory smakowe i składniki odżywcze zawarte $\mathrm{w}$ produkcie $\mathrm{w}$ porównaniu $\mathrm{z}$ pozostałymi metodami termicznymi utrwalania żywności [6]. Podczas zamrażalniczego przechowywania produktów roślinnych zachodzą procesy fizyczne, biochemiczne, chemiczne, enzymatyczne, jak i zmiany mikrobiologiczne, które mają wpływ na zawartość związków odżywczych. Zmiany zawartości witamin w owocach i warzywach zależą głównie od czasu i temperatury przechowywania oraz czynników zewnętrznych. Wpływ tych czynników może powodować ubytki witaminy $\mathrm{C}$ w produktach roślinnych. Papryka jest bogatym źródłem witaminy $\mathrm{C}$, która podczas przechowywania może ulegać reakcji utleniania pod wpływem działania jonów metali $\left(\mathrm{Fe}^{3+}\right.$ lub $\left.\mathrm{Cu}^{2+}\right)$ lub światła. Czynniki te wpływają znacząco na straty kwasu askorbinowego. Straty witaminy można ograniczyć przez przechowywanie w temperaturze bliskiej $0{ }^{\circ} \mathrm{C}$ w kontrolowanej atmosferze $\mathrm{i}$ bez dostępu światła [3].

Celem pracy było określenie wpływu czasu i temperatury zamrażalniczego przechowywania na wybrane cechy charakteryzujące skład chemiczny oraz teksturę owoców papryki.

\section{Material i metody badań}

Materiał doświadczalny stanowiły owoce czerwonej i żółtej papryki (kraj pochodzenia - Hiszpania) odmiany 'California' zakupione w markecie. Świeże, całe owoce pakowano (po 3 sztuki, masa $500 \mathrm{~g}$ ) w torebki do mrożenia (wykonane z folii PPPE) o pojemności $1 \mathrm{dm}^{3}$, zamykano elastycznymi klipsami, zamrażano i poddawano zamrażalniczemu przechowywaniu przez 9 tygodni w dwóch wariantach temperaturowych $-20 \pm 1{ }^{\circ} \mathrm{C}$ i $-80 \pm 3,3^{\circ} \mathrm{C}$. Przygotowano po 3 sztuki opakowań z każdego rodzaju papryki. Zamrażanie i zamrażalnicze przechowywanie odbywało się $\mathrm{w}$ zamrażarce typu Samsung (Samsung Electronics, Suwon, Korea Południowa). Zastosowanie dwóch wariantów temperaturowych miało na celu porównanie wpływu głębokiego mrożenia $\mathrm{w}$ ultraniskiej temperaturze $\left(-80^{\circ} \mathrm{C}\right)$ na zmiany tekstury owoców papryki 
oraz zmiany zawartości witaminy $\mathrm{C}$ podczas przechowywania. Zmiany te wynikają z częściowej utraty ciągłości tkanek na skutek zachodzącej podczas procesu zamrażania przemiany fazowej wody $\mathrm{w}$ lód. Istotnym elementem $\mathrm{w}$ tych przemianach jest prędkość zamrażania, która zależy między innymi od temperatury otoczenia. Niższe temperatury zamrażania sprzyjają utrzymaniu wyższej jakości utrwalanego produktu [4].

W badanym materiale oznaczano: zawartość suchej masy [17], kwasowość miareczkową [14], zawartość witaminy C (kwasu L-askorbinowego KA i całkowitego kwasu askorbinowego - sumy kwasu L- askorbinowego i dehydroaskorbinowego KDA) [15] oraz teksturę poprzez pomiar siły potrzebnej do przecięcia owocu i siły potrzebnej do przebicia skórki owocu [27]. Zawartość KA oraz sumy KA i KDA oznaczano metodą Tillmansa [15]. W celu przygotowania próbek do analiz owoce papryki rozdrabniano za pomocą ceramicznego noża i łączono z 2-procentowym roztworem kwasu szczawiowego, co zapewniało ochronę przed degradacją KA i KDA w czasie wykonywania analizy. Homogenat sączono, następnie miareczkowano mianowanym roztworem odczynnika Tillmansa. W celu usunięcia związków barwnych miareczkowanie wykonywano w obecności rozpuszczalnika organicznego - benzenu. Do przeprowadzenia redukcji kwasu dehydroaskorbinowego do kwasu askorbinowego używano siarczku sodu, następnie nadmiar siarczków strącano roztworem chlorku rtęci(II) (EUROCHEM BGD, Tarnów, Polska) i oznaczano zawartość sumy KA i KDA za pomocą miareczkowania 2,6-chlorofenoloindofenolem (POCH, Gliwice, Polska). Zawartość KA i całkowitego kwasu askorbinowego wyrażano $\mathrm{w} \mathrm{mg} \cdot 100 \mathrm{~g}^{-1}$ produktu.

W celu określenia zmian twardości papryki poddawano ją testowi wytrzymałości na deformację przy użyciu analizatora tekstury SHIMADZU EZ-LX (Shimadzu Co., Japonia) z oprogramowaniem Trapezjum X. Mierzono siłę, przy której produkt uległ trwałej deformacji aż do momentu przebicia jego skórki. Prędkość przesuwu noża wynosiła $1,5 \mathrm{~mm} / \mathrm{s}$. W chwili przebicia skórki i przecięcia owocu rejestrowano wartość siły $\mathrm{F}_{\max }[\mathrm{N}]$. Testy wykonywano na wyciętych z papryki prostopadłościanach o wymiarach $15 \times 15 \times 5 \mathrm{~mm}$. Test przecięcia przebiegał z użyciem ostrza w kształcie litery „V” (tzw. test Wernera-Platzera), natomiast test przebicia skórki - z wykorzystaniem przystawki przebijającej.

Wszystkie analizy chemiczne wykonano w co najmniej 3 powtórzeniach, a analizy tekstury przeprowadzono w 8 powtórzeniach. Oznaczenia wykonano w produkcie świeżym (co oznaczono jako stan „0"), a następnie po kolejnych tygodniach (1 - 9) jego zamrażalniczego przechowywania. Materiał zamrożony rozmrażano do analiz w temp. $20^{\circ} \mathrm{C}$.

Wyniki opracowano statystycznie. Przeprowadzono jednoczynnikową analizę wariancji. Do określenia istotności różnic pomiędzy wartościami średnimi parametrów 
badanej papryki zastosowano test t-Studenta $(\mathrm{p}=0,05)$. Obliczenia wykonano w programie Excel 2010.

\section{Wyniki i dyskusja}

Dobór odpowiednich parametrów zamrażalniczego przechowywania papryki pozwala zachować jej dobrą jakość nawet w dłuższym okresie składowania. Podczas dziewięciu tygodni zamrażalniczego przechowywania owoców papryki zachodziły w nich zmiany wszystkich badanych wskaźników. W przypadku suchej masy zaobserwowano stopniowy, istotny wzrost jej zawartości (tab. 1).

W papryce przechowywanej w temp. $-80^{\circ} \mathrm{C}$ końcowa zawartość suchej masy była istotnie mniejsza niż $\mathrm{w}$ przechowywanej $\mathrm{w}-20^{\circ} \mathrm{C}$. Ubytki suchej masy $\mathrm{w}$ papryce przechowywanej w niższej temperaturze wyniosły $6,8 \%$ (papryka czerwona) i 9,3\% (papryka żółta), natomiast w wariancie wyższej temperatury były one znacznie większe i wynosiły 14,8 \% (papryka czerwona) i 17 \% (papryka żółta).

Tabela 1. Zawartość suchej masy w papryce czerwonej i żółtej w zależności od czasu i temperatury zamrażalniczego przechowywania [\%]

Table 1. Content of dry matter in red and yellow peppers depending on time period and temperature of storage [\%]

\begin{tabular}{|c|c|c|c|c|}
\hline \multirow{3}{*}{$\begin{array}{c}\text { Czas przechowywania } \\
\text { Time period of storage } \\
\text { [tydzień / week] }\end{array}$} & \multicolumn{4}{|c|}{ Temperatura przechowywania / Temperature of storage $\left[{ }^{\circ} \mathrm{C}\right]$} \\
\hline & -20 & -80 & -20 & -80 \\
\hline & \multicolumn{2}{|c|}{ Papryka czerwona / Red pepper } & \multicolumn{2}{|c|}{ Papryka żółta / Yellow pepper } \\
\hline 0 & \multicolumn{2}{|c|}{$7,50^{\mathrm{a}, \mathrm{A}} \pm 0,03$} & \multicolumn{2}{|c|}{$7,08^{\mathrm{a}, \mathrm{B}} \pm 0,02$} \\
\hline 1 & $7,61^{\mathrm{b}, \mathrm{A}} \pm 0,03$ & $7,56^{\mathrm{a}, \mathrm{A}} \pm 0,03$ & $7,14^{\mathrm{a}, \mathrm{A}} \pm 0,02$ & $7,12^{\mathrm{a}, \mathrm{A}} \pm 0,04$ \\
\hline 2 & $7,72^{\mathrm{c}, \mathrm{A}} \pm 0,05$ & $7,61^{\mathrm{a}, \mathrm{A}} \pm 0,05$ & $7,21^{\mathrm{b}, \mathrm{A}} \pm 0,02$ & $7,17^{\mathrm{a}, \mathrm{A}} \pm 0,05$ \\
\hline 3 & $7,81^{\mathrm{c}, \mathrm{A}} \pm 0,04$ & $7,72^{\mathrm{b}, \mathrm{B}} \pm 0,03$ & $7,45^{\mathrm{c}, \mathrm{A}} \pm 0,03$ & $7,21^{\mathrm{a}, \mathrm{B}} \pm 0,03$ \\
\hline 4 & $7,92^{\mathrm{c}, \mathrm{A}} \pm 0,06$ & $7,78^{\mathrm{b}, \mathrm{B}} \pm 0,04$ & $7,62^{\mathrm{d}, \mathrm{A}} \pm 0,04$ & $7,30^{\mathrm{b}, \mathrm{B}} \pm 0,04$ \\
\hline 5 & $8,01^{\mathrm{c}, \mathrm{A}} \pm 0,05$ & $7,81^{\mathrm{b}, \mathrm{B}} \pm 0,03$ & $7,64^{\mathrm{d}, \mathrm{A}} \pm 0,03$ & $7,38^{\mathrm{b}, \mathrm{B}} \pm 0,05$ \\
\hline 6 & $8,21^{\mathrm{d}, \mathrm{A}} \pm 0,04$ & $7,86^{\mathrm{b}, \mathrm{B}} \pm 0,04$ & $7,9^{\mathrm{e}, \mathrm{A}} \pm 0,04$ & $7,51^{\mathrm{c}, \mathrm{B}} \pm 0,03$ \\
\hline 7 & $8,34^{\mathrm{e}, \mathrm{A}} \pm 0,04$ & $7,9^{\mathrm{b}, \mathrm{B}} \pm 0,03$ & $8,02^{\mathrm{e}, \mathrm{A}} \pm 0,05$ & $7,62^{\mathrm{d}, \mathrm{B}} \pm 0,04$ \\
\hline 8 & $8,51^{\mathrm{f}, \mathrm{A}} \pm 0,03$ & $7,96^{\mathrm{b}, \mathrm{B}} \pm 0,06$ & $8,24^{\mathrm{f}, \mathrm{A}} \pm 0,03$ & $7,69^{\mathrm{d}, \mathrm{B}} \pm 0,04$ \\
\hline 9 & $8,61^{\mathrm{g}, \mathrm{A}} \pm 0,02$ & $8,01^{\mathrm{b}, \mathrm{B}} \pm 0,03$ & $8,31^{\mathrm{f}, \mathrm{A}} \pm 0,04$ & $7,74^{\mathrm{d}, \mathrm{B}} \pm 0,02$ \\
\hline
\end{tabular}

Objaśnienia / Explanatory notes:

0 - badanie przeprowadzono na świeżej papryce / the study was conducted on fresh pepper. W tabeli przedstawiono wartości średnie \pm odchylenia standardowe / Table shows mean values \pm standard deviations; $\mathrm{n}=3$ ); $\mathrm{a}, \mathrm{b}$ - wartości średnie oznaczone różnymi małymi literami w kolumnach różnią się statystycznie istotnie $(\mathrm{p} \leq 0,05) /$ mean values in columns and denoted by different small letters differ statistically significantly $(\mathrm{p} \leq 0.05) ; \mathrm{A}, \mathrm{B}$ - wartości średnie oznaczone różnymi dużymi literami $\mathrm{w}$ wierszach różnią się statystycznie istotnie $(\mathrm{p} \leq 0.05) /$ mean values in rows and denoted by different capital letters differ statistically significantly $(\mathrm{p} \leq 0.05)$. 
Na podstawie wyników zawartości suchej masy w owocach papryki czerwonej i żółtej stwierdzono statystycznie istotne różnice wynikające zarówno z czasu, jak i temperatury przechowywania. Podobny wzrost zawartości suchej masy zaobserwowano podczas zamrażalniczego przechowywania truskawek [22] oraz bulw ziemniaków przechowywanych w chłodni [28]. Utrata części wody zawartej w owocach skutkuje utratą jędrności, skraca ich trwałość i obniża wartość handlową [11]. Większą wartość użytkową, przy mniejszym ubytku wody z tkanek, zachowały owoce papryki przechowywane $\mathrm{w}-80^{\circ} \mathrm{C}$.

W czasie zamrażalniczego przechowywania papryki zaobserwowano niewielkie ubytki wody, na co wskazuje stopniowy wzrost zawartości suchej masy podczas 9 tygodni przechowywania (tab. 1). Ubytki wilgoci związane były z wystąpieniem wycieku soku komórkowego w wyniku uszkodzenia struktury komórkowej. Było to widoczne w przypadku papryki przechowywanej w wyższej temperaturze. Przechowywanie papryki w temp. $-20{ }^{\circ} \mathrm{C}$ spowodowało większe uszkodzenia związane $\mathrm{z}$ przemianą fazową wody w lód w porównaniu z temp. $-80^{\circ} \mathrm{C}$.

Kwasowość ogólna (miareczkowa) świeżej papryki żółtej i czerwonej wynosiła $0,25 \mathrm{~g}$ kwasu jabłkowego na $100 \mathrm{~g}$ produktu (rys. 1). Wartość ta jest zgodna z danymi literaturowymi [19]. W papryce zamrożonej w ciągu dwóch pierwszych tygodni jej przechowywania obserwowano istotny wzrost kwasowości ogólnej. W kolejnych tygodniach przechowywania nastąpiła stabilizacja wartości tego parametru. Nie stwierdzono statystycznie istotnych różnic pod względem kwasowości ogólnej, wynikających z zastosowania różnych temperatur zamrażalniczego przechowywania.

Podobnie jak w niniejszej pracy, wzrost kwasowości ogólnej zaobserwowano w zamrażalniczo przechowywanych truskawkach [22] oraz w czerwonej papryce przechowywanej w modyfikowanej atmosferze [20]. W badaniach, które przeprowadzili Gonzales-Castro i wsp. [5], odnotowano z kolei zmniejszenie zawartości kwasów organicznych w mrożonej papryce 'Padron'. Wyjątkiem był kwas chinowy, którego zawartość wzrosła podczas dwunastu miesięcy zamrażalniczego przechowywania tej papryki.

Obecność kwasów organicznych ma decydujący wpływ na smak i zapach surowców roślinnych. Zastosowanie nieodpowiednich warunków przechowywania, takich jak zbyt niska temperatura (poniżej $5{ }^{\circ} \mathrm{C}$ ponad $14 \mathrm{dni}$ ) w przypadku owoców ciepłolubnych, do których należy papryka, powoduje występowanie niekorzystnych przemian fizykochemicznych i biologicznych, które przyczyniają się do wzrostu kwasowości ogólnej [23]. W przypadku badanej papryki zaobserwowano prawie dwukrotny wzrost wartości tego parametru, średnio z 0,25 do 0,50 g kwasu jabłkowego/100 g). Pomimo zaobserwowanego wzrostu kwasowość ogólna badanych owoców papryki wynosząca ok. $0,5 \%$ jest poziomem stosunkowo niskim w porównaniu np. $\mathrm{z}$ jabłkami [24]. 


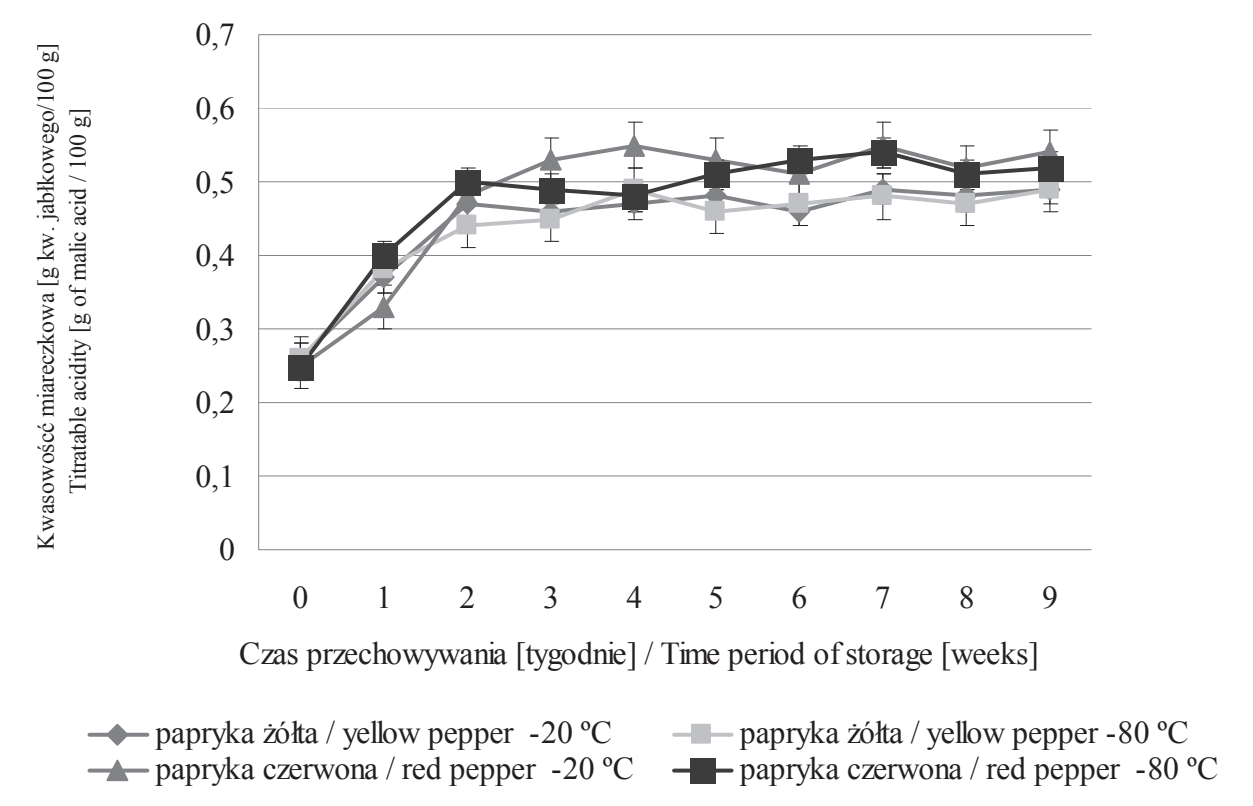

Rys. 1. Zmiany kwasowości miareczkowej w papryce czerwonej i żółtej w zależności od czasu i temperatury zamrażalniczego przechowywania

Fig. 1. Changes in titratable acidity in red and yellow peppers depending on time period and temperature of freezing storage

Zawartość kwasu L-askorbinowego (KA) w świeżych owocach papryki żółtej i czerwonej przed zamrożeniem i przechowywaniem wynosiła odpowiednio: 238,21 i $200,82 \mathrm{mg} / 100 \mathrm{~g}$, (tab. 2), a całkowitego kwasu askorbinowego: 272,85 i $288,99 \mathrm{mg} / 100 \mathrm{~g}$ (rys. 2). Oznacza to, że witamina C w świeżej papryce była reprezentowana głównie przez kwas L-askorbinowy, przy czym więcej tego kwasu zawierała papryka żółta, natomiast czerwona była zasobniejsza w całkowity kwas askorbinowy.

W czasie początkowych dwóch tygodni zamrażalniczego przechowywania zarówno w papryce żółtej, jak i w czerwonej, przechowywanych w obu wariantach temperaturowych, nastąpiło gwałtowne zmniejszenie zawartości KA. W następnych tygodniach przechowywania ubytek KA był już niewielki. Pod koniec trwania eksperymentu najmniejszą zawartością KA charakteryzowała się papryka czerwona, przechowywana w temp. $-20{ }^{\circ} \mathrm{C}$, natomiast najmniejszy ubytek zawartości KA zaobserwowano w papryce czerwonej przechowywanej w temp. $-80{ }^{\circ} \mathrm{C}(54,99 \mathrm{mg})$. Końcowa zawartość KA była największa w papryce żółtej, przechowywanej w temp. 
$-80{ }^{\circ} \mathrm{C}$. Pod koniec składowania straty KA w owocach papryki żółtej i czerwonej przechowywanych $\mathrm{w}$ temp. $-20{ }^{\circ} \mathrm{C}$ wyniosły odpowiednio: 34,8 i $40,4 \%$, natomiast w temp. $-80^{\circ} \mathrm{C}-27,4$ i $36,7 \%$.

Tabela 2. Zawartość kwasu L-askorbinowego w papryce czerwonej i żółtej [mg/100 g] w zależności od czasu i temperatury zamrażalniczego przechowywania

Table 2. Content of L-ascorbic acid in red and yellow peppers $[\mathrm{mg} / 100 \mathrm{~g}]$ depending on time period and temperature of freezing storage

\begin{tabular}{|c|c|c|c|c|}
\hline \multirow{3}{*}{$\begin{array}{c}\text { Czas przechowywania } \\
\text { Time period of storage } \\
\text { [tydzień / week] }\end{array}$} & \multicolumn{4}{|c|}{ Temperatura przechowywania / Temperature of storage $\left[{ }^{\circ} \mathrm{C}\right]$} \\
\hline & -20 & -80 & -20 & -80 \\
\hline & \multicolumn{2}{|c|}{ Papryka czerwona / Red pepper } & \multicolumn{2}{|c|}{ Papryka żółta / Yellow papper } \\
\hline 0 & \multicolumn{2}{|c|}{$200,82^{\mathrm{aA}} \pm 3,35$} & \multicolumn{2}{|c|}{$238,21^{\mathrm{aB}} \pm 3,36$} \\
\hline 1 & $168,43^{\mathrm{b}, \mathrm{A}} \pm 3,30$ & $169,30^{\mathrm{b}, \mathrm{A}} \pm 1,68$ & $165,38^{\mathrm{b}, \mathrm{A}} \pm 5,01$ & $183,61^{\mathrm{b}, \mathrm{B}} \pm 6,68$ \\
\hline 2 & $150,91^{\mathrm{c}, \mathrm{A}} \pm 2,96$ & $157,27^{\mathrm{c}, \mathrm{A}} \pm 5,93$ & $154,50^{\mathrm{c}, \mathrm{A}} \pm 4,41$ & $165,72^{\mathrm{c}, \mathrm{B}} \pm 2,96$ \\
\hline 3 & $146,60^{\mathrm{c}, \mathrm{A}} \pm 1,48$ & $154,03^{\mathrm{c}, \mathrm{B}} \pm 5,92$ & $151,04^{\mathrm{c}, \mathrm{A}} \pm 5,92$ & $163,47^{\mathrm{c}, \mathrm{B}} \pm 7,36$ \\
\hline 4 & $145,99^{\mathrm{c}, \mathrm{A}} \pm 2,86$ & $153,32^{\mathrm{c}, \mathrm{A}} \pm 5,58$ & $148,79^{\mathrm{c}, \mathrm{A}} \pm 5,72$ & $162,02^{\mathrm{c} . \mathrm{B}} \pm 4,30$ \\
\hline 5 & $141,41^{\mathrm{c}, \mathrm{A}} \pm 4,29$ & $150,88^{\mathrm{c}, \mathrm{B}} \pm 3,69$ & $147,44^{\mathrm{c}, \mathrm{A}} \pm 1,43$ & $160,53^{\mathrm{c}, \mathrm{B}} \pm 5,73$ \\
\hline 6 & $139,14^{\mathrm{c}, \mathrm{A}} \pm 4,22$ & $150,93^{\mathrm{c}, \mathrm{B}} \pm 2,85$ & $145,11^{\mathrm{c}, \mathrm{A}} \pm 4,23$ & $156,35^{\mathrm{c} \cdot \mathrm{B}} \pm 3,86$ \\
\hline 7 & $137,78^{\mathrm{c}, \mathrm{A}} \pm 2,81$ & $149,37^{\mathrm{c}, \mathrm{B}} \pm 1,40$ & $146,58^{\mathrm{c}, \mathrm{A}} \pm 5,64$ & $154,77^{\mathrm{c}, \mathrm{A}} \pm 8,44$ \\
\hline 8 & $132,60^{\mathrm{c}, \mathrm{A}} \pm 4,19$ & $149,38^{\mathrm{c}, \mathrm{B}} \pm 2,71$ & $143,69^{\mathrm{c}, \mathrm{A}} \pm 4,19$ & $156,11^{\mathrm{c}, \mathrm{B}} \pm 2,15$ \\
\hline 9 & $130,80^{\mathrm{c}, \mathrm{A}} \pm 2,78$ & $145,84^{\mathrm{d}, \mathrm{B}} \pm 1,30$ & $141,92^{\mathrm{c}, \mathrm{A}} \pm 5,57$ & $150,66^{\mathrm{d}, \mathrm{B}} \pm 2,79$ \\
\hline
\end{tabular}

Objaśnienia jak pod tab. 1. / Explanatory notes as in Tab. 1.

Podobnie jak w przypadku kwasu L-askorbinowego, czas przechowywania miał istotny wpływ na zawartość całkowitego kwasu askorbinowego (KA i KDA) - rys. 2. W początkowym okresie zamrażalniczego przechowywania odnotowano gwałtowne zmniejszenie zawartości KA i KDA, natomiast od czwartego tygodnia tempo zmian było mniejsze. Straty całkowitego kwasu askorbinowego w owocach papryki żółtej i czerwonej przechowywanych w wyższej temperaturze wyniosły odpowiednio: 43,5 i $49,02 \%$, a w temp. $-80{ }^{\circ} \mathrm{C}-41,2$ i $44,2 \%$. W przypadku tego parametru nie zaobserwowano statystycznie istotnych zmian wynikających z zastosowania różnych temperatur zamrażalniczego przechowywania papryki.

Porównanie końcowej zawartości KA $(130,80 \div 150,66 \mathrm{mg} / 100 \mathrm{~g}$ - tab. 2) i sumy KA i KDA (ok. $150 \mathrm{mg} / 100 \mathrm{~g}$ - rys. 2) prowadzi do stwierdzenia, że po zakończeniu doświadczenia udział KA w sumie KA i KDA był dominujący w papryce przechowywanej $\mathrm{w}$ obu wariantach temperaturowych, ale jego zawartość była istotnie większa w materiale przechowywanym w temp. $-80{ }^{\circ} \mathrm{C}$. 


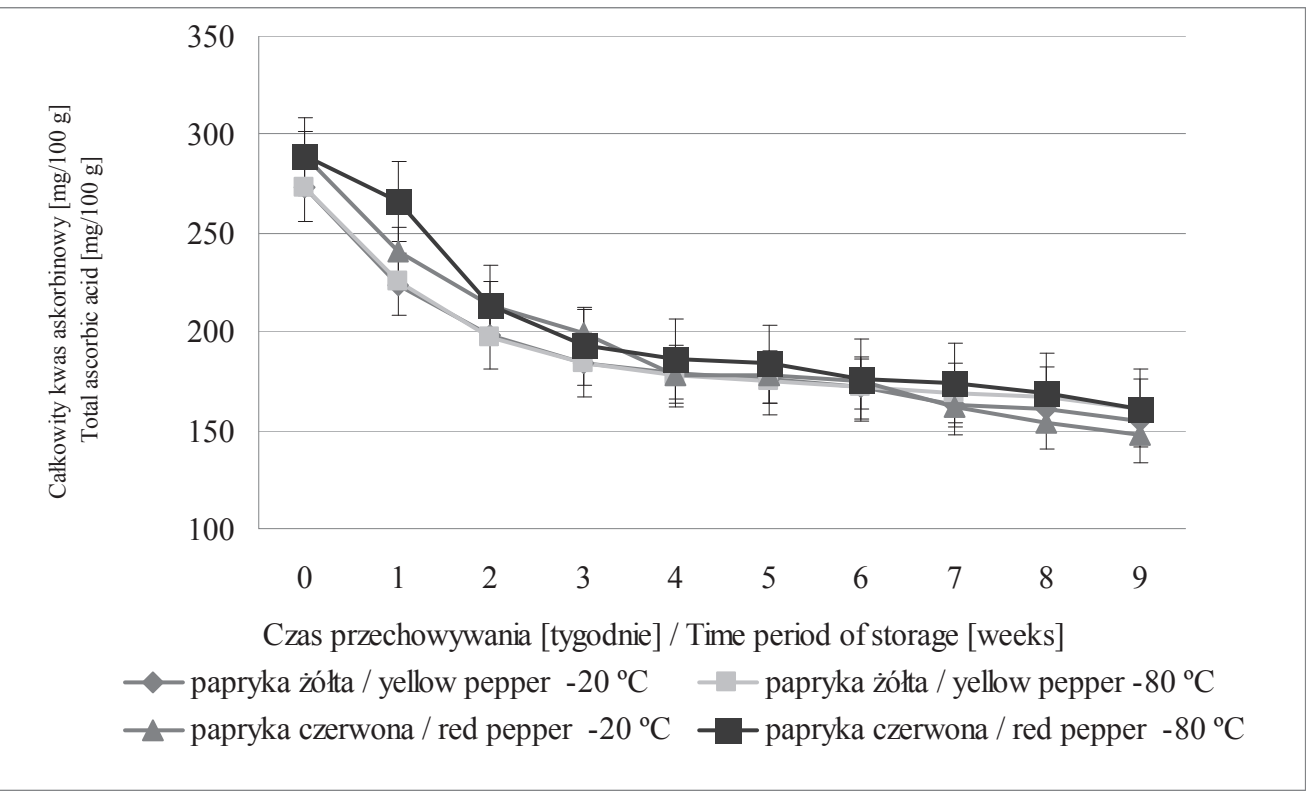

Rys. 2. Zmiany zawartości całkowitego kwasu askorbinowego w papryce czerwonej i żółtej w zależności od czasu i temperatury zamrażalniczego przechowywania

Fig. 2. Changes in content of total ascorbic acid in red and yellow peppers depending on time period and temperature of freezing storage

Leong i Oey [9] przeprowadzili badania na kilku gatunkach owoców (morele, czereśnie, brzoskwinie, śliwki, nektarynki i czerwona papryka) i stwierdzili niski ilościowy stosunek KA do KDA. Mogło to wynikać z zachodzącego podczas ekstrakcji procesu utlenienia KA do KDA. Wyjątek stanowiły owoce czerwonej papryki, w których obecność czynników chelatujących lub inhibitorów oksydazy kwasu askorbinowego chroniła przed utlenianiem witaminy $\mathrm{C}$.

Zmiany zawartości witamin w warzywach zależą głównie od czasu i temperatury przechowywania oraz czynników zewnętrznych. Witamina $\mathrm{C}$ jest jednym z najmniej trwałych związków, łatwo ulga utlenieniu, rozkłada się także pod wpływem promieniowania ultrafioletowego, $\mathrm{w}$ podwyższonej temperaturze oraz $\mathrm{w}$ obecności metali ciężkich [2]. Palich i Pukszta [16] wykazali istotny ubytek tej witaminy $(30 \div 40 \%$ sumy KA i KDA) w okresie 5-miesięcznego przechowywania zielonego groszku $\mathrm{i}$ truskawek w różnych wariantach temperaturowych $\left(-18^{\circ} \mathrm{C},-8^{\circ} \mathrm{C}\right.$ oraz w temperaturze zmiennej $\left.-18 \div-8{ }^{\circ} \mathrm{C}\right)$. Największy ubytek wystąpił podczas przechowywania $\mathrm{w}$ temperaturze zmiennej, natomiast najmniejszy - w temperaturze stałej $-18{ }^{\circ} \mathrm{C}$. Podobne zmniejszenie zawartości całkowitego kwasu askorbinowego $(47 \div 60 \%)$ odnotowano w ciągu 8 miesięcy zamrażalniczego przechowywania różnych odmian truska- 
wek [22]. Niższa temperatura przechowywania sprzyja zachowaniu większych ilości witaminy $\mathrm{C}$, co potwierdzają także badania prowadzone na różnych odmianach kapusty brukselskiej [21].

Zamrażanie $\mathrm{w}$ porównaniu $\mathrm{z}$ innymi procesami (jak ogrzewanie czy suszenie) powoduje niewielkie ubytki witaminy $\mathrm{C}$ w papryce, co potwierdzili Leong i Oey [9]. Do podobnych wniosków doszli Pobereżny i Wszelaczyńska [18], którzy badali zmiany zawartości witaminy $\mathrm{C}$ m.in. w papryce czerwonej oraz jej przetworach otrzymanych w wyniku mrożenia i suszenia.

Zapotrzebowanie dorosłego człowieka na witaminę $\mathrm{C}$ w zależności od stanu fizjologicznego organizmu waha się w granicach $35 \div 70 \mathrm{mg}$ na dobę [12]. Na podstawie uzyskanych wyników badań można stwierdzić, że mimo strat zachodzących podczas zamrażalniczego przechowywania $50 \mathrm{~g}$ mrożonej papryki może zapewnić pokrycie dziennego zapotrzebowania organizmu dorosłego człowieka na witaminę C.

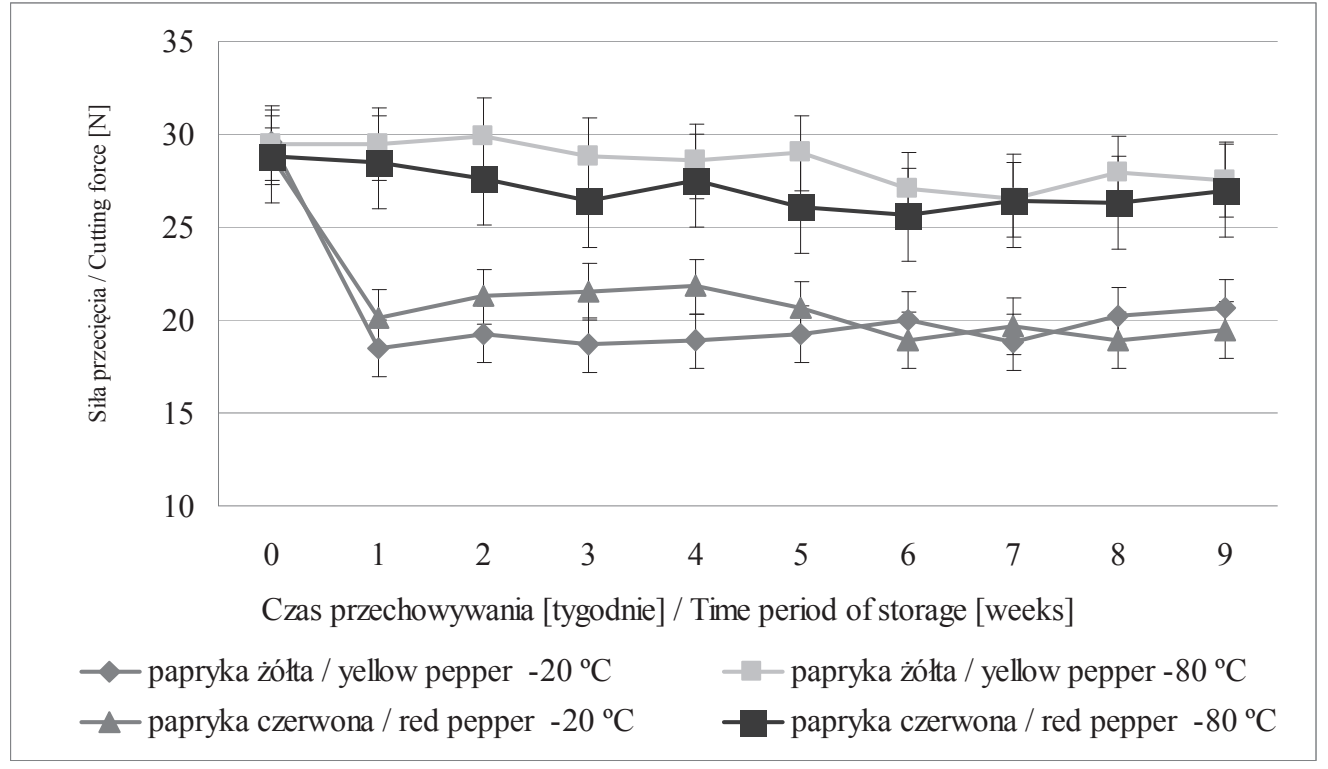

Rys. 3. Zmiany siły potrzebnej do przecięcia owoców papryki czerwonej i żółtej w zależności od czasu i temperatury zamrażalniczego przechowywania

Fig. 3. Changes in force needed to cut through red and yellow peppers depending on time period and temperature of freezing storage

Paprykę analizowano pod względem tekstury, wykonano test cięcia owoców i przebicia skórki. Wartość siły potrzebnej do przecięcia owoców papryki przechowywanych w temp. $-80^{\circ} \mathrm{C}$ była stosunkowo stabilna i istotnie wyższa niż użyta w stosunku do papryki przechowywanej $\mathrm{w}-20^{\circ} \mathrm{C}$ (rys. 3). W przypadku papryki przechowywa- 
nej w temp. $-20^{\circ} \mathrm{C}$ wartość tego wskaźnika obniżyła się istotnie w pierwszym tygodniu zamrażalniczego przechowywania. Nie stwierdzono istotnych różnic wartości siły potrzebnej do przecięcia owoców papryki czerwonej i żółtej przechowywanych w tym samym wariancie temperaturowym. Procentowe zmniejszenie siły cięcia papryki czerwonej $\mathrm{i}$ żółtej przechowywanej $\mathrm{w}$ temp. $-20{ }^{\circ} \mathrm{C}$ wyniosło odpowiednio: 32,36 i $30,04 \%$, natomiast papryki składowanej w temp. $-80{ }^{\circ} \mathrm{C}-6,24$ i $6,77 \%$.

Wyższe wartości siły potrzebnej do przecięcia produktu wskazują na mniejsze uszkodzenia spowodowane przemianą fazową wody w lód. Powstające podczas zamrażania kryształki były mniejsze i nie spowodowały mechanicznego uszkodzenia tkanek $\mathrm{w}$ takim stopniu, $\mathrm{w}$ jakim miało to miejsce $\mathrm{w}$ przypadku wyższej temperatury zamrażania i przechowywania $\left(-20{ }^{\circ} \mathrm{C}\right)$. Papryka przechowywana w temp. $-80{ }^{\circ} \mathrm{C}$ po rozmrożeniu była nadal jędrna $\mathrm{w}$ przeciwieństwie do papryki przechowywanej $\mathrm{w}$ temp. $-20^{\circ} \mathrm{C}$, która stała się miękka i wiotka.

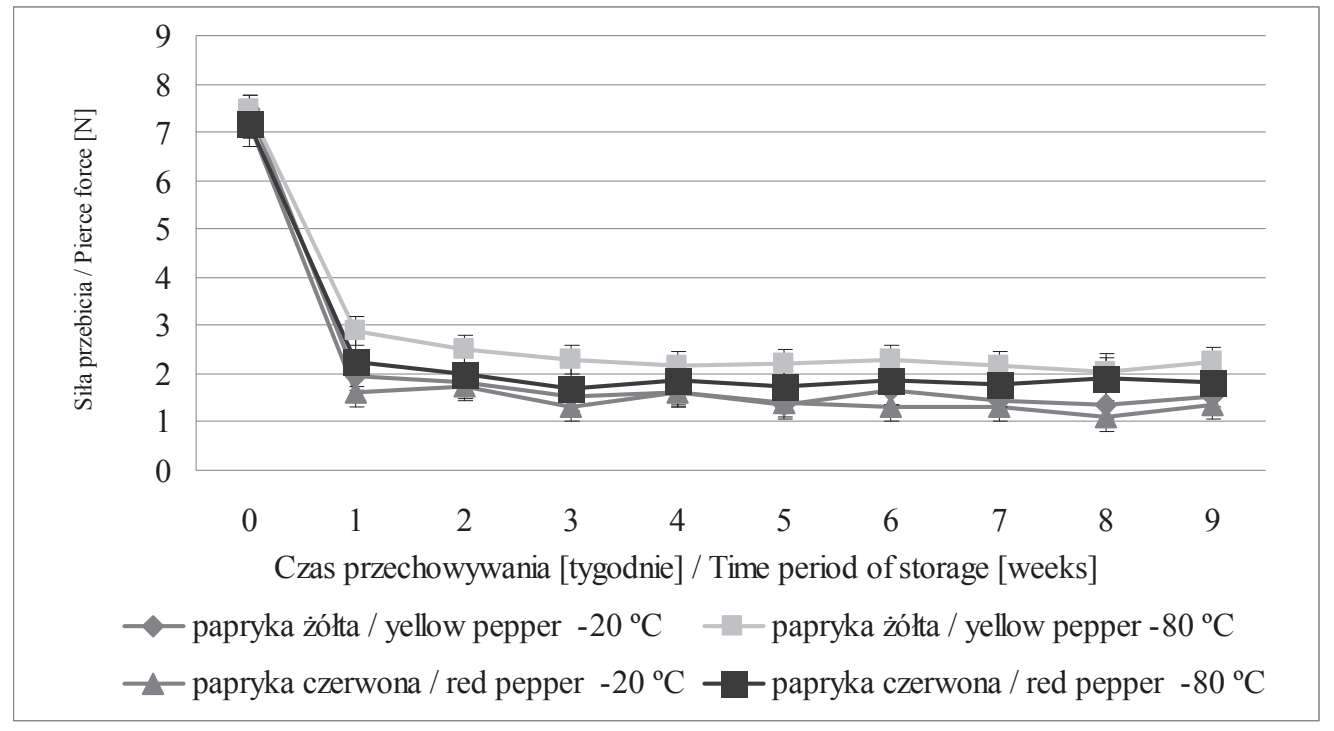

Rys. 4. Zmiany siły potrzebnej do przebicia skórki owoców papryki czerwonej i żółtej w zależności od czasu i temperatury zamrażalniczego przechowywania

Fig. 4. Changes in force needed to pierce red and yellow peppers depending on time period and temperature of freezing storage

Drugim parametrem umożliwiającym określenie zmian tekstury papryki podczas zamrażalniczego przechowywania był pomiar siły potrzebnej do przebicia skórki owocu. W stosunku do stanu papryki świeżej siła potrzebna do przebicia skórki owoców obu rodzajów papryki gwałtownie zmalała w ciągu pierwszego tygodnia ich zamrażalniczego przechowywania, zarówno $\mathrm{w}$ temp. $-80{ }^{\circ} \mathrm{C}$, jak i w $-20^{\circ} \mathrm{C}$ (rys. 4 ). Zmiany 
zachodzące w kolejnych tygodniach były już niewielkie. Większe siły potrzebne były do przebicia skórki owoców papryki czerwonej i żółtej przechowywanych w temp. $-80{ }^{\circ} \mathrm{C}$ niż w $-20^{\circ} \mathrm{C}$, ale tylko w przypadku papryki żółtej wartość tej siły była istotnie zróżnicowana $\mathrm{w}$ zależności od temperatury zamrażalniczego przechowywania. $\mathrm{Na}$ podstawie analizy wartości siły przebicia skórki papryki żółtej przechowywanej w temp. $-80^{\circ} \mathrm{C}$ stwierdzono różnice statystycznie istotne tylko w pierwszym tygodniu przechowywania. W kolejnych tygodniach parametr ten był stabilny.

Podczas rozmrażania papryki przechowywanej w temp. $-20{ }^{\circ} \mathrm{C}$ obserwowano niewielki wyciek, który wskazuje na przerwanie ciągłości tkanek owoców. Niekorzystne zmiany związane ze zmniejszeniem jędrności owoców papryki w trakcie przechowywania zaobserwowali także Liu i wsp. [10]. Zmniejszenie jędrności warzyw i owoców podczas przechowywania związane jest m.in. z naturalnymi procesami metabolicznymi - oddychaniem i transpiracją. Zastosowanie niskich temperatur podczas przechowywania skutecznie spowalnia te procesy. Wolak i Kluza [27] potwierdzają korzystny wpływ niskich temperatur przechowywania, a także szybkiego czasu zamrażania na teksturę papryki.

Zmiany chemiczne i biochemiczne w produktach roślinnych podczas zamrażalniczego przechowywania są niewielkie, jednak warunki zamrażania i zamrażalniczego przechowywania mają wpływ na głębokość tych zmian. Wyniki prowadzonych badań wskazują, że w zamrożonych owocach papryki, niezależnie od zastosowanych warunków temperaturowych, największe tempo zmian badanych wskaźników (zawartości kwasu L-askorbinowego i całkowitego kwasu askorbinowego, kwasowości ogólnej oraz parametrów tekstury) miało miejsce w początkowym okresie przechowywania (1 $\div 2$ tygodni). Po zakończeniu eksperymentu wyższą jakością charakteryzowały się owoce papryki zamrożonej i przechowywanej w temp. $-80{ }^{\circ} \mathrm{C}$ niż przechowywane $\mathrm{w}$ $-20{ }^{\circ} \mathrm{C}$.

\section{Wnioski}

1. Przechowywanie owoców papryki czerwonej i żółtej w temp. $-80{ }^{\circ} \mathrm{C}$ ograniczyło w nich wzrost zawartości suchej masy i związany z nim ubytek wody.

2. W obu zastosowanych temperaturach zamrażalniczego przechowywania odnotowano istotne straty kwasu L-askorbinowego oraz całkowitego kwasu askorbinowego, jednak końcowa zawartość kwasu L-askorbinowego w papryce czerwonej i żółtej oraz przechowywanej w temp. $-80{ }^{\circ} \mathrm{C}$ była istotnie większa niż w przechowywanej $\mathrm{w}-20^{\circ} \mathrm{C}$.

3. Kwasowość ogólna papryki czerwonej i żółtej wzrosła istotnie, niezależnie od temperatury zamrażalniczego przechowywania. 
4. Stwierdzono ochronny wpływ przechowywania $\mathrm{w}$ temperaturze $-80{ }^{\circ} \mathrm{C}$ na stan miąższu owoców, na co wskazują wyższe siły potrzebne do przecięcia owoców papryki przechowywanej $\mathrm{w}$ tym wariancie temperaturowym.

\section{Literatura}

[1] Biggs M., McVicar J., Flowerdew B.: Wielka księga warzyw, ziół i owoców. Dom Wyd. Bellona, Warszawa 2007, ss. 69-71.

[2] Cieślewicz J., Grzelakowska A.: Wpływ warunków przechowywania na zawartość witaminy C i karotenoidów w żółtej papryce konserwowej. Bromat. Chem. Toksykol., 2012, 4, 1246-1253.

[3] Gajewski M.: Przechowalnictwo warzyw. SGGW, Warszawa 2005, ss. 41-52, 70-76, 159-160.

[4] Gaziński B.: Przechowalnictwo owoców i warzyw. W: Technika chłodnicza dla praktyków - przechowalnictwo żywności. Red. B. Gaziński. Systherm Technik, Poznań 2013, ss. 245-252, 274-280.

[5] Gonzalez-Castro M.J., Oruna-Concha M.J., Lopez-Hernandezz J., Simal-Lozano J.: Effects of freezing on the organic acids content of frozen green beans and Padron peppers. Zeits. Lebenm. Forsch., 1997, 204, 365-368.

[6] Jarczyk A., Płocharski W.: Technologia produktów owocowych i warzywnych. Wyd. WSHE im. prof. S. Pieniążka, Skierniewice 2010, ss. 108-109.

[7] Kuczuk A.: Wyniki produkcyjno-ekonomiczne uprawy papryki słodkiej w warunkach ekologicznego systemu produkcji. J. Res. Appl. Agric. Enging., 2011, 56 (3), 243-249.

[8] Kunachowicz H., Nadolna I., Iwanow K., Przygoda B.: Wartość odżywcza wybranych produktów spożywczych i typowych potraw. PZWL, Warszawa 1997, ss. 61-62, 73-75.

[9] Leong S.Y., Oey I.: Effects of processing on anthocyanins, carotenoids and vitamin C in summer fruits and vegetables. Food Chem., 2012, 133, 1577-1587.

[10] Liu L., Wei Y., Shi F., Liu C., Liu X., Ji S.: Intermittent warming improves postharvest quality of bell peppers and reduces chilling injury. Postharvest Biol. Technol., 2015, 101, 18-25.

[11] Maalekuu K., Elkind Y., Tuvia-Alkalai S., Shalom Y., Fallik E.: Quality evaluation of three sweet pepper cultivars after prolonged storage. Adv. Hortic. Sci., 2003, 17, 187-191.

[12] Maćkowiak K., Torliński L.: Współczesne poglądy na rolę witaminy C w fizjologii i patologii człowieka. Nowiny Lekarskie, 2007, 76 (4), 349-356.

[13] Markowska J., Polak E., Kasprzyk I.: Technologie chłodzenia i mrożenia w przetwórstwie żywności. Przem. Spoż., 2014, 68 (9), 10-15.

[14] Mokrosińska K.: Stężenie jonów wodorowych $(\mathrm{pH})$ i kwasowość miareczkowa. W: Technologia chłodnictwa żywności, składniki pokarmowe i kontrola ich przemian. Red. S. Michałowski. Wyd. PŁ, Łódź 1995, ss. 106-122.

[15] Mokrosińska K.: Witamina C. W: Technologia chłodnictwa żywności, składniki pokarmowe i kontrola ich przemian. Red. S. Michałowski. Wyd. PŁ, Łódź 1995, ss. 190-209.

[16] Palich P., Pukszta T.: Zmiany zawartości witaminy C mrożonych warzyw i owoców w czasie przechowywania. Chłodnictwo, 2001, 36 (7), 43-45.

[17] PN-EN 12145:2001. Soki owocowe i warzywne. Oznaczanie całkowitej suchej substancji. Metoda grawimetryczna oznaczania ubytku masy w wyniku suszenia.

[18] Pobereżny J., Wszelaczyńska E.: Wpływ metod konserwacji na wybrane cechy jakościowe owoców i warzyw znajdujących się w handlu detalicznym. Inż. Aparatura Chem., 2013, 2, 92-94.

[19] Rembiałkowska E., Hallmann E.: Zmiany zawartości związków bioaktywnych w owocach papryki marynowanej z uprawy ekologicznej i konwencjonalnej. J. Res. Appl. Agric. Enging., 2008, 53 (4), 51-57.

[20] Rydzykowski T., Michalska-Pożoga I.: Wpływ pakowania (MAP) na trwałość i zmiany przechowalnicze świeżej rozdrobnionej papryki czerwonej. Post. Techn. Przetw. Spoż., 2014, 1, 29-33.

[21] Sikorska-Zimny K., Badełek E.: Zmiany zawartości witaminy C w czasie przechowywania dwóch odmian kapusty brukselskiej Ajax F1 i Louis F1. Zesz. Nauk. Inst. Ogrod., 2014, 22, 121-127.

[22] Skupień K.: Ocena wybranych cech jakościowych świeżych i mrożonych sześciu odmian truskawki. Acta Sci. Pol., Hortorum Cultus, 2003, 2 (2), 115-123. 
[23] Sobkowicz G.: Towaroznawstwo i przechowalnictwo produktów rolnych. Wyd. AR, Wrocław 1995, ss. 9-17.

[24] Suszyna J.: Kwasowość owoców odmian jabłoni w okresie największej podaży dla przetwórstwa. Zesz. Nauk. Inst. Sad. Kwiac., 2007, 15, 109-116.

[25] Świetlikowska K.: Surowce spożywcze pochodzenia roślinnego. Wyd. SGGW, Warszawa 2008, ss. 141-143.

[26] Trajer M., Dyngus M.: Krajowa produkcja, spożycie oraz promocja owoców i warzyw. Biul. Inf. ARR, 2013, 6 (3), 19-21.

[27] Wolak S., Kluza F.: Ocena tekstury zamrażanej papryki słodkiej wynikająca z wartościowania testów cięcia i wycieku rozmrażalniczego. Chłodnictwo, 2002, 37 (1), 42-43.

[28] Wójcik-Stopczyńska B., Baczyńska A.: Zmiany zawartości niektórych składników bulw podczas przechowywania w szafie chłodniczej. Ziemniak Polski, 2014, 1, 33-38.

[29] Zalega J., Szostak-Węgierek D.: Żywienie w profilaktyce nowotworów. Cz. I. Polifenole roślinne, karotenoidy, błonnik pokarmowy. Prob. Hig. Epidem., 2013, 94 (1), 41-49.

\section{EFFECT OF FROZEN STORAGE ON CONTENT OF VITAMIN C AND SOME SELECTED FEATURES OF SWEET PEPPERS (CAPSICUM ANNUUM L.)}

S u m m a y

The objective of the research study was to determine the effect of time period ( 9 weeks) and frozen storage temperatures $\left(-20{ }^{\circ} \mathrm{C}\right.$ and $\left.-80{ }^{\circ} \mathrm{C}\right)$ on the content of some selected ingredients (L-ascorbic acid LAA, the total of L-ascorbic acid and L-dehydroascorbic acid - LAA and DHAA, and dry matter), general acidity, and texture of sweet peppers (yellow and red) of the 'California' variety. During frozen storage of the whole pepper fruits, a gradual increase was reported in the content of dry matter. It varied significantly depending on the time period and storage temperature. In the peppers stored at $-80{ }^{\circ} \mathrm{C}$, the final content of dry matter was significantly lower than that in the fruits stored at $-20^{\circ} \mathrm{C}$. The increase in the content of dry matter in the fruits of yellow and red pepper stored at a lower temperature was $6.8 \%$ and $9.3 \%$, respectively; as for the second variant of a higher temperature, the increase in the content of dry matter was significantly higher and amounted to $14.8 \%$ (red peppers) and $17 \%$ (yellow peppers). Those results prove a lower loss of water in pepper fruits stored at a lower temperature. A decrease was reported in the content of L-ascorbic acid and in the total of L-ascorbic acid and L-dehydroascorbic acid; that decrease was the highest during the initial period of storage. After the experiment was accomplished, the average losses of $\mathrm{L}$-ascorbic acid in the red peppers stored at temperatures of $-80{ }^{\circ} \mathrm{C}$ and $-20{ }^{\circ} \mathrm{C}$ were $37 \%$ and $41 \%$, respectively, while in the yellow peppers: $28 \%$ and $35 \%$. The decrease in the total of LAA and DHAA in red the peppers stored at temperatures of $-80{ }^{\circ} \mathrm{C}$ and $-20{ }^{\circ} \mathrm{C}$ was $49 \%$ and $56 \%$, respectively, while in the yellow peppers: $41 \%$ and $43 \%$. The final content of the total acidity in the peppers stored at the two temperatures was similar, but a significantly higher content of L-ascorbic acid was found in the fruits of the two types of peppers stored at a temperature of $-80{ }^{\circ} \mathrm{C}$. As for yellow peppers stored at the two storing temperature variants, their total acidity increased ca. twice from 0.26 to $0.49 \mathrm{mg} / 100 \mathrm{~g}$ of malic acid. As for the red peppers stored at temperatures of -20 and $-80{ }^{\circ} \mathrm{C}$, their total acidity rose from 0.25 to 0.54 and to $0.52 \mathrm{mg} / 100 \mathrm{~g}$ of malic acid, respectively. The acidity value changed irrespective of the applied temperature of frozen storage. The texture of peppers changed in particular during the first week of the frozen storage. Those changes were more intense in the fruits stored at $-20^{\circ} \mathrm{C}$.

Key words: frozen pepper, vitamin C, dry matter, acidity, texture 